\title{
The Underlying Motives for Earnings Management: Directors' Perspective
}

\author{
H. A. Hashim, Z. Salleh, and A. Mohamad Ariff
}

\begin{abstract}
This paper provides evidence on the motives for directors to manage earnings. Adapting theory of reasoned actions, we examine three different motives (i.e. altruistic, speculative, and pressure from affiliated parties) for directors to manage earnings. We find that the primary motive for directors to be involved in earnings management activity is derived from altruistic motivation, which refers to the motive that involves concern about the benefits of company. Directors work hard to meet market expectations and are more concerned about their company's reputation rather than their own personal benefits.
\end{abstract}

Index Terms-Directors, earnings management, motivation.

\section{INTRODUCTION}

Earnings management practices raise important issue facing the accounting profession. This issue has grown tremendously for the past two decades and continues to be of interest to academics and standard setters [1]-[2]. The interests in examining earnings management is grounded in the assumption that this behavior misleads financial statement users and sometimes are precursors of more serious activities such as fraudulent financial reporting [3]. Although many countries have emphasized on the role of good corporate governance practices in reducing the risk of earnings management behavior, it is nevertheless a global phenomenon. Managers are still engaged in earnings management [4]. Despite the importance of this area of research, difficulty in differentiating between management's true belief and management's intent to manipulate earnings remains a challenge for archival empirical research to convincingly document earnings management behavior [5].

One of the main roles of directors is to monitor and constrain earnings management [6]. Their role as the apex of corporate governance systems is crucial to the success and survival of the firms. Past studies recognize the importance of boards as a crucial internal control mechanism and suggest that an effective board helps mitigate earnings management activities [6]-[8]. Though ample empirical evidence concludes that effective boards help reduce earnings management, the earnings management issues never end. Accounting scandals such as Satyam Computer Services in India and many others (e.g. Lehman Brothers in United

Manuscript received May 8, 2013; revised July 12, 2013. The study is supported by the Fundamental Research Grant Scheme (FRGS, Vote No.: 59232) provided by Ministry of Higher Education (MOHE) of Malaysia. The authors thank the Ministry for its research support.

The authors are with the Universiti Malaysia Terengganu, Kuala Terengganu, Terengganu, 21030 Malaysia (e-mail: hafizaaishah@umt.edu.my, zalailah@umt.edu.my, akmalia.ariff@umt.edu.my).
States, Sino-Forest Corporation in Canada, Olympus Corporation in Japan, Anglo Irish bank in Ireland) show that corporate governance alone might not be able to withhold directors from earnings management behavior.

Thus, to tackle this issue, we conduct a study to understand motives behind earnings management. We use survey instrument and focus our sample on directors sitting on the board of Malaysian public listed companies. Our decision is based on the importance of director's role in assessing company policy on earnings guidance and other forward-looking information [9]. As earnings play a very important role in determining share price, director often face incentives and feel pressured to meet others and their own pre-determined target [10].

The rest of the study is organized as follows. The second section of this paper discusses the literature on this area of study. The third section describes the methodology employed. The fourth section discusses the results. The conclusion and future research are set out in section five.

\section{LITERATURE REVIEW}

Reference [11] state that earnings management may occur '... when managers use judgment in financial reporting and in structuring transactions to alter financial reports to either mislead some stakeholders about the underlying economic performance of the company or to influence contractual outcomes that depend on reported accounting numbers.' Additionally, [12] suggests that '...when management's number-choice is made with an eye to its effect on net or comprehensive income, it is engaging earnings management'. In other words, earnings management can be defined as manipulating reported earnings so that they inaccurately present economic earnings [13].

Past studies suggest that there are different underlying motives for firms to engage in earnings management. According to [4], altruistic motivation, speculative motivation, and pressure from affiliated parties are three different motives that normally drive earnings management Altruistic motivation refers to personal perceptions and behavior tendencies in earnings management for the benefits of companies [4]. Examples are to avoid loss of confidence by employees and banks, to prevent a drop in company share prices, to reduce tax burdens, to proceed with the development of important projects, and to reach the threshold of public listings. According to [10], managers feel pressured to meet earnings projections because market tends to punish companies that fail to meet analysts' expectations. Findings from a survey by [5] report that eighty percent of chief financial officers choose to decrease discretionary 
expenditures when faced with the possibility of earnings falling below the company desired earnings target. The executives surveyed believe that hitting earnings benchmarks builds market credibility and helps to maintain or increase the stock price of their companies.

Motivation for earnings management can also stem from speculative motivation, which refers to the motive of deriving personal gains [4]. The intention to manage earnings may possibly arise from the need to increase personal bonuses and remunerations, to gain opportunities for promotion, and to meet annual profit targets. As noted by [14], shareholders commonly use earnings directly as a basis for awarding bonuses and indirectly as a reference points for awarding executive stock options for senior managers. Study by [13] finds that managers smooth earnings when their compensation contract is tied to firm performance. Similarly, [15] report that managers tend to use earnings management to boost their compensation.

Tendency to manage earnings may also be due to requirements from other parties such as supervisors, colleagues, accountants, shareholders, creditors, or analysts [4]. Pressures from affiliated parties, which may arise from either opinion or request, may give a great tendency for managers to manage earnings. In a review of earnings management in China, [16] document that controlling shareholders are reluctant to see their company being delisted from the Chinese Stock Exchange. Due to that, there are strong incentives for earnings manipulation. In the setting where ownership structure is highly concentrated such as in China, the motive for managers to manipulate earnings is driven mainly for the benefit of controlling shareholders.

\section{RESEARCH METHOD}

To gather data regarding the motivations for earnings management, a questionnaire survey was conducted. The survey instrument was based on the 27 potential questionable earnings management intention (measured by Likert 5-point scales) designed by [17]. The questionnaires were issued to directors of the sample firms through the mail in October 2012. The sample firms were ramdomly selected from a list of public listed companies on the Bursa Malaysia website. A total of 300 questionnaires were mailed. The respondents were given 3 month to complete and return the questionnaire to researcher. Out of the 300 questionnaires, 31 valid questionnaires were returned and used for discussions. The collected data was analysed using the Statistical Package for the Social Science (SPSS) software.

In interpreting the motives for involvement in earnings management behaviour, our study adapts the theory of reasoned action [18]. There are two constructs under this theory; attitude towards behaviour and subjective norms. The attitude towards behaviour construct incorporates the individual's belief about the likelihood that the behaviour will result in a particular outcome and the person's evaluation of that outcome. The subjective norm construct is the conviction of particular referents and individual's incentive to obey with the referents [17]. Altruistic and speculative motivations can be classified into attitude towards behaviour construct while pressure from affiliated parties falls under subjective norms construct.

\section{RESULTS AND DiSCUSSION}

TABLE I: DESCRIPTIVE STATISTIC

\begin{tabular}{|c|c|c|c|c|}
\hline Descriptive items & $\begin{array}{c}\text { Frequenc } \\
\mathrm{y}\end{array}$ & $\begin{array}{l}\text { Per } \\
\text { cent }\end{array}$ & $\begin{array}{c}\text { Valid } \\
\text { Per cent }\end{array}$ & $\begin{array}{c}\text { Cumulative } \\
\text { Per cent }\end{array}$ \\
\hline \multicolumn{5}{|l|}{ Gender } \\
\hline Male & 24 & 77.4 & 77.4 & 77.4 \\
\hline Female & 6 & 19.4 & 19.4 & 100 \\
\hline \multicolumn{5}{|l|}{ Age } \\
\hline 30 or under & 3 & 9.7 & 9.7 & 9.7 \\
\hline $31-40$ & 8 & 25.8 & 25.8 & 35.5 \\
\hline $41-50$ & 7 & 22.6 & 22.6 & 58.1 \\
\hline 51 or older & 12 & 38.7 & 38.7 & 96.8 \\
\hline No answer & 1 & 3.2 & 3.2 & 100 \\
\hline \multicolumn{5}{|l|}{ Race } \\
\hline Malay & 20 & 64.5 & 64.5 & 64.5 \\
\hline Chinese & 9 & 29.0 & 29.0 & 93.5 \\
\hline No Answer & 2 & 6.5 & 6.5 & 100 \\
\hline \multicolumn{5}{|l|}{ Highest education } \\
\hline First degree & 15 & 48.4 & 48.4 & 48.4 \\
\hline Master degree & 6 & 19.4 & 19.4 & 67.8 \\
\hline Others & 9 & 29 & 29 & 96.8 \\
\hline No Answer & 1 & 3.2 & 3.2 & 100 \\
\hline \multicolumn{5}{|l|}{ Professional qualification } \\
\hline Yes & 14 & 45.2 & 45.2 & 45.2 \\
\hline No & 17 & 54.8 & 54.8 & 100 \\
\hline \multicolumn{5}{|l|}{ Position in company } \\
\hline CEO & 1 & 3.2 & 3.2 & 3.2 \\
\hline Executive directors & 10 & 32.3 & 32.3 & 35.5 \\
\hline Independent directors & 7 & 22.6 & 22.6 & 58.1 \\
\hline Others & 13 & 41.9 & 41.9 & 100 \\
\hline \multicolumn{5}{|l|}{ Current position } \\
\hline 10 or under & 21 & 67.7 & 67.7 & 67.7 \\
\hline $11-20$ & 5 & 16.1 & 16.1 & 83.8 \\
\hline No answer & 5 & 16.1 & 16.1 & 100 \\
\hline
\end{tabular}

Percentage of total assets

owned in the company

Less than 1 percent

More than 5 percent

No answer

\begin{tabular}{cccc}
6 & 19.4 & 19.4 & 19.4 \\
6 & 19.4 & 19.4 & 38.8 \\
1 & 3.2 & 3.2 & 42 \\
18 & 58 & 58 & 100 \\
\hline
\end{tabular}

Compensation

Less than RM100,000

RM100,000-RM299,000

RM300,000-RM599,000

RM600,000-RM999,000

RM1,000,000 and above

No answer

Involved in decision making

\begin{tabular}{lcccc} 
making & 19 & 61.3 & 61.3 & 61.3 \\
Yes & 11 & 35.5 & 35.5 & 96.8 \\
No & 1 & 3.2 & 3.2 & 100 \\
No answer & \\
\hline
\end{tabular}

Based on Table I, $24(77.4 \%)$ of the respondents are male and $6(19.4 \%)$ are female. With regards to age, the youngest respondent is 27 years old while the oldest is 76 years old. More than half of the respondents are Malay (64.5\%). For the highest education, $15(48.4 \%)$ out of the 31 respondents have a first degree and the remaining respondents have either a masters degree $(19.4 \%)$ or other professional qualifications 
$(29 \%)$

$10(32.3 \%)$ out of the 31 respondents are executive directors, $7(22.6 \%)$ are independent non-executive directors while the remaining respondents are in other categories, i.e. finance manager, account manager; 14 (45.2\%). The respondents have been serving in their current position for a period ranged between 1 to 20 years. A majority of the respondents have less than 1 percent of total assets ownership in the company. Meanwhile, 6 respondents $(19.4 \%)$ receive a compensation of less than RM100,000, 7 respondents (22.6\%) receive between RM100,000 - RM299,000, 4 respondents (12.9\%) receive between RM300,000 RM599,000 and 4 respondents (12.9\%) receive a compensation greater than RM600,000 a year for 2011 . Interestingly, $19(61.3 \%)$ of the respondents have been involved in decisions that touch upon earnings management during their tenure.

TABLE II: RESULTS OF STATISTICS

\begin{tabular}{lccc}
\hline \hline Items & $\begin{array}{c}\text { Altruistic } \\
\text { motivation }\end{array}$ & $\begin{array}{c}\text { Speculative } \\
\text { motivation }\end{array}$ & $\begin{array}{c}\text { Pressure from } \\
\text { affiliated parties. }\end{array}$ \\
\hline Mean & 2.3902 & 1.9548 & 2.1425 \\
\hline $\begin{array}{l}\text { Std. } \\
\text { deviation }\end{array}$ & 0.5589 & 0.8209 & 0.7859 \\
\hline \hline
\end{tabular}

The main objective of our study is to identify the motive for directors to be involved in earnings management. The mean of the data can be used as a tool to measure the primary motives that lead directors to be involved in earnings management. From Table II above, the higher mean is from altruistic motivation, which is 2.7102 with a standard deviation of 0.5589 . This shows that earnings management intention by directors in Malaysia is driven mainly for meeting market expectations. In other words, the main motive for directors to engage in earnings management is to benefit the company. Directors seem to believe that hitting earnings benchmark impresses capital providers and build market confidence. This finding supports prior evidence reported by [5] and [15].

The second highest motivation for directors' involvement in earnings management is the pressure by affiliated parties, which has a mean of 2.1425 and a standard deviation of 0.7859. The finding suggests that, in making decision, directors face pressure from other parties who have interest in the company. The finding supports recent review by [16] which suggest that controlling shareholders influence earnings management behaviour in China. As Malaysia is generally known as a country that also has high concentrated corporate ownership structure, the institutional setting in Malaysia may possibly explain the results related to the pressure from affiliated parties in our study.

Meanwhile, the speculative motivation is the last motive for directors' engagement in earnings management. The speculative motivation has a mean of 1.9548 and a standard deviation of 0.8209. In conclusion, Malaysian directors seem to concern more about company performance and the satisfaction of others rather than concerning about their own personal interests.

\section{CONCLUSION}

Our study documents evidence on motives for directors to manage earnings. Our study contributes to earnings management research on the behavioural perspective which is not observable through archival empirical research. Using survey instruments, our results indicate that the primary motive for directors to manage earnings is to meet market expectations and to satisfy other parties rather than for their own benefit. Results of our study support [5] by indicating that manager are willing to give up real economic value to manage earnings for the purpose of meeting analysts and investors' expectations. The findings of our study are useful in assisting the regulators in efforts towards enhancing the quality of the reported financial information. Any regulatory approach must consider that there are underlying motives behind directors' inclination to manage earnings. Future research can add more to these findings, for example by looking at the perspective of other parties such as the preparers of financial statement as well as the auditors.

\section{REFERENCES}

[1] M. L. Defond, "Earnings quality research: Advances, challenges and future research," Journal of Accounting and Economics, vol. 50, pp. 402-409, 2010.

[2] P. M. Dechow, A. P. Hutton, J. H. Kim, and R. G. Sloan, "Detecting earnings management: A new approach," Journal of Accounting Research, vol. 50, no. 2, pp. 275-334, 2012.

[3] K. A. Merchant and J. Rockness, "The ethics of managing earnings: An empirical investigation," Journal of Accounting and Public Policy, vol. 13, pp. 79-94, 1994.

[4] M. C. Chen and Y. C. Tsai, "Earnings management types and motivation: A study in Taiwan," Social Behaviour and Personality, vol. 38, no.7, pp. 955-962, 2010.

[5] J. R. Graham, C. R. Harvey, and S. Rajgopal, "The economic implications of corporate financial reporting," Journal of Accounting and Economics, vol. 40, pp. 3-73, 2005.

[6] A. Marra, P. Mazzola, and A. Prencipe, "Board monitoring and earnings management pre and post IFRS," The International Journal of Accounting, vol. 46, pp. 205-230, 2011.

[7] A. Klein, "Audit committee, board of director characteristics and earnings management," Journal of Accounting and Economics, vol. 33, pp. 375-400, 2002.

[8] K. V. Peasnell, P. F. Pope, and S. Young, "Board monitoring and earnings management: Do outside director's influence abnormal accruals?" Journal of Business Finance \& Accounting, vol. 32, no. 7-8, pp. 1311-1346, 2005.

[9] R. J. Kueppers, "Earnings guidance and the board of directors," The Corporate Board, pp. 1-5, March/April 2010.

[10] N. Mizik, "The theory and practice of myopic management," Journal of Marketing Research, vol. 47, pp. 594-611, 2010.

[11] P. M. Healy and J. M. Wahlen, "A review of the earnings management literature and its implications for standard setting," Accounting Horizons, vol. 13, no. 14, pp. 365-383, 1999.

[12] R. L. Weil, "Quality of earnings and earnings management: A primer for audit committee members," The American Institute of Certified Public Accountants (AICPA), pp. 1-3, February 2009.

[13] A. Goel and A. V. Thakor, "Why do firms smooth earning?" The Journal of Business, vol. 76, no. 1, pp. 151-192, 2003.

[14] K. V. Peasnell, P. F. Pope, and S. Young, "Accrual management to meet earnings targets: UK evidence pre- and post-Cadbury," British Accounting Review, vol. 32, pp. 415-445, 2000.

[15] G. Latridis and G. Kadorinis, G. "Earnings management and firm financial motives: A financial investigation of UK listed firms," International Review of Financial Analysis, vol. 18, pp. 164-173, 2009.

[16] J. Yang, J. Chi, and M. Young, "A review of earnings management in China and its implication," Asian-Pacific Economic Literature, vol. 26, no.1, pp. 84-92, 2012.

[17] N. Uddin and P. R. Gillet, "The effects of moral reasoning and self-monitoring on CFO intentions to report fraudulently on financial statements," Journal of Business Ethics, vol. 40, pp. 15-32, 2002.

[18] I. Ajzen and M. Fishbein, Understanding Attitudes and Predicting Social Behaviour, NJ: Prentice Hall, 1980. 


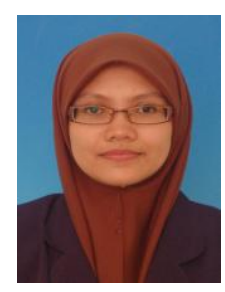

Hafiza A. Hashim has a Ph.D. in Accounting from University of Malaya, Malaysia in 2009. Her field of study is financial reporting quality related to earnings management and corporate governance. She is currently a senior lecturer in the Faculty of Management and Economics, Universiti Malaysia Terengganu, Terengganu, Malaysia. She publishes in the area of financial reporting and corporate governance. Her research interests are earnings quality, earnings management, and ownership structure.

Dr. Hashim is an associate member of the Malaysian Institute of Accountants and Malaysian Finance Association. Her most recent award is the Best Ph.D. Student awarded by the Graduate School of Business, Faculty of Business and Accountancy, University of Malaya.

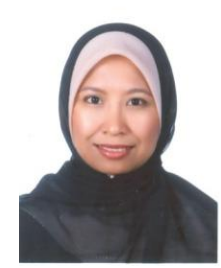

Zalailah Salleh has a Ph.D. in Accounting from Griffith University, Australia in 2009. Her field of study is audit committee roles in relation to auditor-client negotiation process. She is currently a senior lecturer in the Faculty of Management and Economics, Universiti Malaysia Terengganu, Terengganu, Malaysia. She publishes in the area of financial reporting and auditing. Her research interests audit. are in the area of corporate governance and external

Dr. Salleh is a chartered accountant and a member of Malaysian Institute of Accountants.

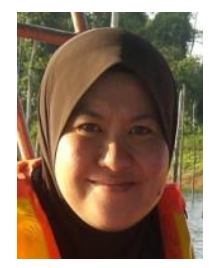

Akmalia Mohamad Ariff has a Ph.D. in Accounting obtained from the University of Auckland, New Zealand in 2011. Her field of study is financial reporting quality related to voluntary disclosure of intangibles from the perspective of East Asian markets. She is currently a senior lecturer in the Faculty of Management and Economics, Universiti Malaysia Terengganu, Terengganu, Malaysia. She publishes in the area of financial reporting and corporate governance. Her research interests are financial reporting quality, voluntary disclosures, market valuation, and East Asian studies.

Dr. Mohamad Ariff is an associate member of the Malaysian Institute of Accountants. Her most recent award is being listed on the University of Auckland's Dean of Graduate Studies List in recognition of excellence achieved with her Ph.D. thesis. 